\title{
Moldova: A Country in Turmoil
}

\author{
Tanya Basok and Alexander Benifand
}

Recently there have been numerous violations of political freedom and ethnic minority rights in the former Soviet republic of Moldova. These human rights abuses have resulted from two significant political processes: the rise of Romanian nationalism; and separatist movements in the Transdniester and the Gagauz regions. Political opponents and members of ethnic minorities are ruthlessly persecuted in all regions; Moldova proper, Gagauzia, and Transdniestria. As Anatol Tsaranu, Chairman of the Parliamentary Commission on State Security and Military Affairs, observed:

In a country with no established democratic traditions, a country which has experienced chronic political instability in recent years, a country going through a severe economic crisis, extraordinary phenomena can be expected. The impetus could be provided by the most ordinary event (Prikhodko 1993, 3).

The two political developmentsRomanian nationalism and antiMoldovan separatism-have to be placed within the context of the two opposing political pressures being exerted on Moldova: one from Russia, which wants to see Moldova reintegrated into a renewed Russian Empire; and the other from Romania, which would prefer reunification with Moldova. Transdniestria and Gagauzia are leaning strongly towards Russia, Moldovan nationalists are campaigning for reunification with Romania, and the Moldovan government is trying to remain independent of both. However, the deplorable state of the Moldovan economy is making Moldovan autonomy less viable and is forcing Moldova toward joining the CIS.

\section{Russian Interference}

Russia's interference in the Transdniester conflict in Moldova has occurred through the participation of the 14th Russian Army, under the command of Lieutenant General Alexander Lebed (a protégé of Russian Defense Minister General Pavel Grachev). There is considerable evidence that the 14th Army's actions against Moldova were authorized by the military hierarchy in Moscow and condoned by senior government officials there. The Russian government never tried to prevent several thousand volunteers from Russia from fighting on the side of the Transdniester Republic (TDR) against Moldova. Furthermore, the Russian government increased its economic aid to the TDR. At the same time, negotiations to withdraw the Russian troops from eastern Moldova remain at an impasse (Socor 1993, January 1). The stalemate in the present negotiations have forced Moldova to extend the CSCE's Moldova's Mission by another six months (Socor 1993, November 10).

In March 1991, Yeltsin officially transferred 15,000 troops of the 14th Army to Russian control. His former vice-president, Rutskoi, visited Tiraspol and said that the republic should continue to exist (Europa World Yearbook, 2802-6). According to eyewitnesses, personnel and equipment from the Russian 14th Army participated in the fighting against the Moldovans (Department of State 1993, 850).

On September 13, 1993, Lt. Gen. Aleksandr Lebed, participated in a four-way race for a seat in the Transdniester Republic Supreme Soviet, and won 88 percent of the votes. During his campaign, he pointed out that Russian Federation citizens enjoy full political rights in Transdniester. No Russian civilian or military authority tried to prevent him from joining the Transdniester government (Socor 1993, September 14).
At a news conference in Chisinau on November 1, 1993, the Moldovan side of the joint commission supervising the cease-fire in Transdniester accused the Russian side of multiple violations of the cease-fire agreement. Reported violations include: allowing the penetration of additional Transdniester forces into the "security zone" between the conflicting sides; blocking inspection of suspected Transdniester arms stockpiles in Bendery, where such stockpiles are banned; and tolerating aggressive picketing by Russian Communist groups around the last remaining Moldovan police station and courthouse in Bendery, thus exerting pressure on the Moldovans to leave (Socor 1993, November 4).

Russia has tried to justify its continued presence in the Transdniester region by blaming Romania for the political instability in Moldova. The pro-Yeltsin newspaper, Izvestia, has published an anonymous interview with a Russian Foreign Ministry official in which he stated that "foreign agents" control the Moldovan government. In this interview, the official also stated that the Russian military behaviour in the region is premised on a "possible Moldovan-Romanian joint attack on the [Trans]Dniester Republic" (Socor 1993, November 8).

On September 10, 1993, the Moldovan government issued an official statement describing the recent escalation of Gagauz and Transdniester militancy, as the "direct result" of recent visits to those two would-be republics by Russian parliamentary deputies who support the rebirth of the USSR (Socor 1993, September 13). Yet, when Moldovan Foreign Minister, Nicolae Tiu, addressed the UN General Assembly, he described Russia's 14th Army as the catalyst of the Transdniester conflict and cautioned the international community against granting Russia the 
mandate of "peacemaker" on the territory of the former USSR. He complained of Russia's refusal to admit UN or CSCE observers to the deadlocked talks on the withdrawal of the 14th Army from Moldova and accused the Russian Foreign Ministry of "completely misrepresenting" Russian policy (Socor 1993, October 20, a).

Disregarding the criticism of the Moldovan Government, Russia continues to send economic aid to the selfproclaimed republic, despite the alignment of Transdniester fighters with Yeltsin's opponents in the October confrontation between Parliament and the President. On October 19,1993, Deputy Prime Minister Nikolai Kiba told the Supreme Soviet in Tiraspol that Russia had delivered 35 billion rubles worth of fuel and raw materials to the TDR in the first nine months of 1993. According to Kiba, the deliveries are being handled by Russia's state firm, Rosskontrakt, and are covered by credits extended earlier. He stressed the importance of the deliveries continuing on schedule (Socor 1993, October 20, b).

The Russian President demonstrated his complete indifference to the Moldovan Government by refusing to meet with President Mircea Snegur during his official visit to Moscow on October 18-19, 1993. Snegur had hoped to capitalize on support that the Transdniester Communist fighters had provided during the Moscow rebellion, and on the vocal support which he and Moldova had expressed for Yeltsin throughout that and other crises. The meeting was intended to be used to discuss with Yeltsin the question of the withdrawal of Russian troops from Moldova, the political resolution of the Transdniester issue, the fate of Moldovan detainees in Tiraspol, and other pressing matters. Instead, Snegur was told on the second day of his visit that Yeltsin was indisposed and could not see him (Socor 1993, October 20, c).

The deplorable state of the Moldovan economy is weakening Moldova's resistance to Russia. According to Moldova's State Depart- ment of Statistics, the country's national income dropped 20.2 percent in the first half of 1993, compared with the same period the previous year. Agricultural output, the pillar of Moldova's economy, fell by 36 percent. ITAR-TASS said that experts consider the decline in production to be chronic, due to the unbalanced nature of the economy, the breakdown of traditional economic ties, and the lack of raw materials. Inflation in the first half of 1993 was officially put at 24.3 percent, but the newspaper Nezavisimaya Moldova reckoned it was really 300 percent (Sheehy 1993). Moreover, some of Moscow's policy initiatives are aggravating Moldova's economic situation and further undermining their independence (Socor 1993, November 5). For instance, the excise and value added taxes imposed in August 1993 by Russia on agricultural imports from Moldova, cost Moldova more than 40 billion rubles in lost exports. The magnitude of the economic impact was equal to the previous year's drought, which had necessitated international relief. The new Russian tariffs influenced Moldova's decision to join the CIS Economic Union and ratify Moldova's membership of the CIS.

\section{The Rise of Romanian Nationalism}

The rise of Romanian nationalism in Moldova is apparent in three political developments: (1) the struggle to secede from the USSR (and to gain independence from Russia); (2) the persecution of non-Romanian minorities; and (3) the suppression of separatist movements within Moldova.

The stronghold for nationalist ideas is the Moldovan Popular Front (MPF). The MPF was formed in May 1989, when a number of independent cultural and political groups joined together, united by their common aspirations for separation from the USSR and for reunification with Romania. The MPF was later renamed the Christian Democratic Popular Front (CDPF).

Ideas of Romanian reunification found fertile soil among the Moldovan politicians and the population in gen- eral. During the February 1990 election to the Moldovan Supreme Soviet, none of the independent political groups were officially allowed to support candidates. In fact, most of the 380 deputies elected (some 80 percent) were members of the Communist Party. Yet many were also sympathetic to the aims of the Popular Front. Approximately 40 percent of the new deputies were supported by the Front, and a further $\mathbf{3 0}$ percent were estimated to favour its objectives. Mircea Snegur, a Communist Party member supported by the Popular Front, was elected Chairman of the Supreme Sovieteventually becoming Moldova's de facto President (Europa World Year Book, 2802-6). In August 1991 Moldova declared independence from the USSR.

Since its formation more than four years ago, the Christian Democratic Popular Front has transformed itself from a movement with broad political and popular support to an opposition party with ideals and aspirations no longer held by the majority of Moldovans. Most members of the Moldovan Supreme Soviet and the general population oppose reunification with Romania (Rossiyskaya Gazeta 1993). Despite their lack of popular support, members of the Christian Democratic Popular Front continue to press the Moldovan Supreme Soviet for Romanian reunification.

The maverick party has also confronted Parliament on another contentious issue-membership in the Commonwealth of Independent States. On August 3, 1993, Snegur proposed CIS ratification. Pro-Romanian members of the Supreme Soviet walked out of Parliament, thus creating a political stalemate (for any decision, the Moldovan Parliament requires a two-thirds majority). With the continued absence of deputies from Transdniester, along with approximately 75 others who rarely fulfil their parliamentary functions, it has been difficult for Parliament to ratify any decision. The boycott by the CDPF candidates created a political crisis in Moldova and led to a decision by Par- 
liament to hold pre-term legislative elections in February 1994 (UPI 1993, October 13). Until then, Parliament remains virtually paralysed.

Having moved into the role of political opposition, the CDPF has tried to destabilize Snegur's government. In February 1993, President Snegur declared several times that a coup d'état was being prepared by the CDPF. In February 1993, CDPF members picketed the presidential residence and tried to storm it before a violent confrontation with the police in which several policemen were wounded (Holos Ukrayiny 1993). Around the same time, a letter from "Chernovitskaya Bukovina," reprinted in Moldovan papers, suggested that the Romanian security service, in close contact with the CDPF extremist wing, had set up combat groups comprised of Moldovan volunteers. The Romanian Secret Service intended to use this force to overthrow the President, Prime Minister, and other leaders of the republic, thus facilitating its reunification with Romania. Members of CDPF interpreted Snegur's accusation as an attempt to discredit opposition so that he would be able to carry out reprisals (Prikhodko 1993, 3).

While the CDPF represents extreme Romanian nationalism, it does not hold a monopoly on nationalist sentiments. A temporary commission for inspecting the state media of the Moldovan parliament has proposed a "patriotism exam" for journalists. Before working in the Moldovan state press, journalists would have to recognize the integrity and independence of the Republic in writing. This proposal came from Tudor Topa, chairman of the temporary Parliamentary Commission for Inspecting the Activity of the State Press. During the "party leadership of the press," he headed the press section of the Moldovan Central Committee Communist Party (ITARTASS 1993).

In its effort to build a nation state, the Moldovan Government has taken measures to strengthen the dominance of Romanian culture in this multiethnic country. In August 1989, the
Supreme Soviet of Moldova made Romanian the official language of the Republic, and replaced the Cyrillic alphabet with the Latin one. Officials and employees are now obligated to know both Romanian and Russian. State enterprises are expected to use Romanian as their working language and as of April 1, 1993, records could only be kept in the Romanian language.

Furthermore, personal contacts at work between officials in languages other than Romanian are forbidden. Russian speakers have complained that language requirements have already been used to dismiss ethnic Russians from desirable jobs (Department of State 1993, 853). In Russian and other national schools, Romanian language examinations have already begun (Chala 1993). At the Moldovan State University 17 instructors with Master's and Doctorate degrees were suddenly discharged for "failure to qualify." All of them were nonMoldovans. One of them, the head of the Department of Modern Russia, had signed an open letter protesting the decision of the Ministry of Sciences and Education to cancel Russian philology classes at the University. Her discharge letter said: "Does not qualify for her present position because of her sociopolitical activism aimed against the decisions taken by parliament and the government" (Grevtsev 1993, 9).

The Pirogov Congress of Medical Workers' Association in Moldova issued a document accusing the Public Health Ministry leaders of using language as a cover for persecuting people on ethnic grounds. Due to the new language requirements, almost all non-Romanian administrators have been relieved of their posts in the $\mathrm{Re}$ public's Public Health Departments (ITAR-TASS 1993). This policy of discrimination has been implemented at all levels of educational institutions. Thus, in Chisinau the number of Russian kindergartens has been reduced by half. Previously there were 150 mixed schools in the republic_today the only language of instruction is Romanian. Similarly, two Russian news- papers have closed down (Soldatova 1993).

In addition to discriminating against non-Romanian minorities on the basis of language, the government has denied certain religious denominations the freedom of expression and congregation. The practice of religion is generally free in Moldova. Parliament passed a law in 1992 which codified religious freedoms, but the activities of some religious groups were restricted. The law requires that religious groups be registered with the government and that denominations obtain government approval to hire non-citizens (Department of State 1993, 851).

This law effectively prohibits some denominations. For instance, the government refused to recognize the Metropolitan Seat of Bessarabia (ancient rite), which revived its activities in accordance with the rites of the Romanian Orthodox Church Synod (Rompres 1993). The law also prohibits "proselytizing," although, in practice, street preaching is still possible since Parliament did not provide an adequate legal definition of "proselytizing." Although the Orthodox Church was not designated as the official religion of Moldova, it remains a strong political and religious force. In one village, for example, the mayor requested permission from the local Orthodox Church before a Baptist congregation could build its own church (Department of State 1993, 851-2).

The Moldovan state has been extremely reluctant to grant autonomy to its predominantly non-Moldovan regions: Gagauzia and Transdniester. Almost two-thirds of the Moldovan population of 4.3 million consists of ethnic Romanians. About 600,000 people (14 percent of the entire population) live in the region of Transdniester, of whom about 60 percent are Russian speaking. Within Moldova, Ukrainians (14 percent) and Russians (13 percent) are the two largest minority groups. A Christian Turkic minority, the Gagauz, live primarily in the southern region. The Gagauz are largely Russian-speaking and repre- 
sent about 3.5 percent of the population (Department of State 1993, 851-2).

On January 28, 1990 a referendum on Transdniester autonomy took place in Tiraspol. The predominantly Russian-speaking population voted overwhelmingly to seek greater autonomy for the region on the left bank of the Dniester River. On August 19, 1990 and on September 2, 1990, Gagauz and the Transdniester, respectively, proclaimed themselves autonomous Soviet Socialist Republics. Both declarations were immediately annulled by the Moldovan Supreme Soviet (Europe World Year Book). The Moldovan government has used force to repress separatism, especially in the Transdniester region. In November 1990 inter-ethnic violence followed the announcement of elections to the "Transdniester Supreme Soviet" (ibid.). Clashes continued in 1991 resulting in hundreds of civilian casualties. In June of 1992, heavy fighting broke out in the city of Tighina (Bendery), when separatist forces attacked a Moldovan police station. Moldovan army and police reinforcements were sent to the city, and other Moldovan forces were mobilized to attack the separatist forces (Department of State 1993, 850). A few days later a cease-fire agreement was signed, and since then, the two sides have been trying to negotiate a settlement. However, until now, their disagreements on Transdniester autonomy have not been resolved.

Although the repression of Gagauz separatism has not been as violent as the Transdniester movement, certain incidents have occurred. At the end of March, there were serious disturbances in Komrat, provoked by the suicide of a Gagauz man in a pre-trial detention cell at the Komrat police station. The Gagauz side maintained that the man died as a result of torture. A crowd of 200 to 500 people surrounded the police building, throwing grenades and Molotov cocktails. The police building was burnt to the ground (Selivanov 1993).

In both separatist movements, the Moldovan state refuses to recog- nize claims for autonomy. The Draft Constitution protects the right of minorities to preserve their ethnic identity, however, it fails to guarantee their right to self-determination (Basapress 1993, April 14).

\section{Violence Against Ethnic Minorities in Moldova}

The attitude of the Moldovan state towards its ethnic minorities has been largely benign. Violence against nonRomanians stems mainly from the CDPF and those inspired by its ideas. However, the state is partially responsible for the mistreatment of minorities; first, its language laws have transformed Russian-speaking people into second class citizens, and second, the state has failed to protect its ethnic minorities.

One of the most important principles of the 18,000 strong CDPF is that "the rights of the nation are above the rights of the individual." This principal translates into discrimination against Russians, Ukrainians, Jews, Gagauz, Germans and others (Soldatova 1993). Members of the CDPF reportedly use the slogan, "Let's drown Russians in Jewish blood." They have been kidnapping, beating and raping their opponents (Zarya Pridnestroviya 1992). The Memorial Human Rights Centre $(1992,18)$ reported that volunteer members of the CDPF serving on the Moldovan side of the conflict in the Transdniester region were involved in the beatings of prisoners, general violence, burglary and murder on both the right and the left banks of the Dniester River.Neglect of minority rights and active discrimination culminated with a phase of "antiRussian hysteria" following the brief war in the Transdniester region. Around that time, the mass media spread propaganda about wickedness of non-Romanian people. ${ }^{1}$

Russian cultural monuments were desecrated in Chisinau, and other Moldovan cities and towns (BBC 1992, October 5). Beatings and threats made to the Russian-speaking population became common in the aftermath of the Bendery War and the authorities did nothing to stop them. According to a spokesperson at the U.S. Helsinki Commission, the Moldovan police are ignoring ethnic violence and the harassment of minorities. ${ }^{2}$

Some Jews feel that there has been a rise in anti-Semitism among Romanian nationalists, provoked in part by the crisis in Transdniestria and Moldova's weakness against Russia (Commission on Security and Cooperation in Europe 1993). The CDPF suggested naming a street in honour of General Antonescu-an anti-Semitic Romanian Iron Guard in the 1930s who was responsible for the elimination of 300,000 Jews in Romania, Bessarabia, Northern Bukovina and Transdniestria.

Speaking of some 40,000 to 50,000 Jews still living in Moldova, Leonid Baltsam, a representative of the Moldovan Jewish community at the August 1992 World Jewish Congress in Brussels said, "I hope my forecast is wrong but I cannot help feeling that the life of these people is in serious danger" (Baltsam 1992). Jewish refugees from the left bank received a hostile reception. They were reportedly forced to vacate a shelter in central Chisinau as a result of "anti-Jewish agitation protesting the large number of Jews who had gathered there." 3

While the Moldovan state can hardly be accused of anti-Semitism or other forms of racism, it has been unable to protect Jews and other ethnic minorities from violence. Authorities have been reluctant to recognize antiSemitic incidents and, instead, continue to classify them as acts of hooliganism. For instance, in the city of Sorroki, Jewish graves were desecrated. Leaders of Jewish organizations demanded that this incident be recognized as anti-Semitic, yet the authorities insisted that it was common vandalism. ${ }^{3}$ This impotence and reluctance of the Moldovan authorities to intervene reflects the low priority that protecting minority rights has in comparison to resolving the conflicts in the Transdniester and the Gagauz regions, resisting the mounting pressures from Romania and Russia, and coping with 
the deplorable state of the Moldovan economy.

\section{Abuse of Rights in the Transdniester Republic}

The Transdniester Republic's human rights record is considerably tarnished by its treatment of political prisoners, dissenters and Jews. Five CDPF members have been in a Tiraspol jail since May/June 1992. They have been kept in steel cages and are stoned and spit upon by excited crowds calling for their execution. ${ }^{6}$ They have been on trial since April 1993 on charges of terrorism. On October 11, 1993, the TDR's state prosecutor demanded the death penalty for three of the defendants and prison terms for the others. Numerous international human rights organizations, and European bodies including CSCE, the Council of Europe, and Western embassies in Moldova have noted numerous legal inconsistencies in the trial and have demanded that the defendants be turned over to a lawful court in Chisinau (Socor 1993, October 12).

There have been a number of accusations of politically motivated killings in the Transdniester region in connection with the fighting that took place in 1992. The separatist controlled prosecutor's office in the region has been reluctant to investigate these accusations. Moldovan government police and prosecutors have been dismissed or forced to flee the area. Once removed from the area, central authorities cannot take steps to apprehend or punish those on either side responsible for human rights violations in the region (Department of State 1993, 848). There is one remaining Moldovan police station and courthouse in Bendery, but local Russian Communist groups have been picketing them, demanding that these last seats of Moldovan authority be handed over to the TDR (Socor 1993, September 23).

There has also been political censorship and politically motivated persecution in the TDR. Jamming of Moldovan Radio in the TDR began in 1991, and continued in 1992. Likewise, distribution of the printed media has been restricted. Some individuals in the TDR who oppose the de facto existence of the TDR, have been harassed, dismissed from work, and physically attacked. Doctors and teachers trained outside the TDR have been systematically raided as punishment for their presumed opposition to the TDR ( $\mathrm{Hu}$ man Rights Watch 1993, 239). The Transdniester government has forbidden the use of the Latin alphabet, and its supporters routinely harass Moldovans living within its territory.

Anti-Semitism is an integral part of the official ideology in the TDR. Many of Russia's pro-fascist militarist organizations, such as the Russian Legion and the notorious Pamyat, have participated in attacks on Jews, and their members have infiltrated both nonprofit and government organizations. A faction of the National Salvation Front from Russia was created in the TDR (Basapress 1993, March 19). Russian nationalists in the TDR claim to have "won their first victory over the Zionist-American conspiracy throughout the Soviet Union (Russia)." Among the "conspirators" are Moldova's present government and those in the TDR who support the Moldovan Government and consider themselves citizens of Moldova (ibid.).

The influence of Russia's fascist and Communist ideologists in TDR are extremely strong. The TDR government has awarded orders to the entire editorial board of the anti-Semitic newspaper "Den" (Day). Ideologists and leaders of other anti-Semitic organizations in Russia have been similarly decorated (ibid.).

The Constituent Assembly of the Transdniester branch of the International Slavic Academy of Sciences met recently at the Dniester State University in Tiraspol. Most of the Academy's leading officials and scholars are well known for their anti-Semitic views and include such renowned nationalist activists as Igor Shafarevich who was asked to resign from the Russian Academy of Science for his anti-Semitic publications (Rozenberg 1993).

Deputies of Russia's Supreme Soviet, representing various ultra-na- tionalist organizations, such as Otchizna and the National Salvation Front, frequently visit Gagauzia and Transdniester (Interfax 1993). In June of 1993, a group of deputies from the Supreme Soviet of Russia, led by Sergei Baburin, arrived in the TDR (Basapress 1993, June 22) to commemorate the events of the previous year (Nezavisimaya Gazeta 1993).

Today, in the TDR, the activities of all Jewish organizations have stopped and synagogues have closed. The authorities refuse to register new Jewish organizations and the media is full of anti-Semitic articles. ${ }^{7}$

Although there have been few reported cases of human rights abuses in the Gagauz region, ethnically-motivated violence has occurred. It has been reported that armed Gagauz groups raided non-Gagauz (Moldovan and Bulgarian) villages, plundering livestock and vehicles (Radio Free Europe 1993).

\section{Freedom of Movement Within Moldova}

Persecution of ethnic minorities and violent confrontations have produced significant numbers of refugees within Moldova. Yet, it is difficult for them to escape from one part of Moldova (including its two self-proclaimed republics) to another. Anyone moving within Moldova must state his or her reasons for doing so. A residence permit can be obtained if displaced people stay with relatives, in dormitories or in government supplied accommodation in hotels. The applicant must obtain written permission from the owner of the apartment in which he or she will stay, as well as from all other adult relatives living in the apartment. In practice, there are significant problems associated with finding an apartment or other residence in a country where housing is in such short supply (Information and Research Branch 1993).

\section{Emigration}

According to a poll conducted by the Moldovan Academy of Sciences in September of 1992, 60 percent of Russian-speaking citizens were ready to 
leave Moldova because of "nationalistic" tensions (BBC 1992, October 5). Russian statistics indicate that, between July 1, 1992 and January 31, 1993 (including the peak of the Transdniester conflict and its aftermath), 11,072 people fled from Moldova to Russia, making a total of 191,431 who had arrived from Moldova in the few years prior to January 1993 (Soldatova 1993). Others fled to the Ukraine during the Transdniester war, but many have since returned. For most of the uprooted, possibilities for emigration to the West are limited. Only Jews have an established channel of escape. The exodus of 60,000 Jews from Moldova during the period of $1989-1992^{8}$ reflects the seriousness of the present situation.

The armed conflict between Romanian and Slavic populations of the Transdniester region has affected many Jews. Alison Kaplan and Shimon Chertok estimate that there were 8,000 Jews in the Transdniester region (with 2,500 in Bendery and Tiraspol before the Transdniester War began). Many of them fled the armed confrontations. One-third of the Jews who fled emigrated to Israel. Those who stayed remained anxious to get out (Kaplan 1992; Chertok 1992). According to E. Danilyan, freelance journalist and special representative of the $\mathrm{UN}$ in Moldova, in September of 1992, there remained not more than 10 to $13 \mathrm{Jew}$ ish families in Bendery (Chertok 1992). Among those who still live in Moldova and the TDR, 70 percent have Israeli letters of invitation. ${ }^{9}$ Some Jews have been subjected to the practice of "displacement" prior to leaving. When local residents learn that a family is planning to emigrate, they break the lock on the apartment while the occupants are out and simply move in. When the family returns, they are told that since they are leaving anyway, they can move in with their relatives. The police do not interfere in such instances. ${ }^{10}$

Many Moldovan Jews are reluctant to emigrate to Israel because of the discouraging letters received from compatriots in Israel who experienced difficulties finding decent housing and jobs. In fact, the situation of some recent Moldovan Jewish immigrants in Israel was so desperate that they returned to Moldova. However, upon their return, they said in a public statement that they regretted their actions. They encouraged their relatives not to idealize their former homeland and to remain in Israel (American Association of Russian Jewry 1992).

\section{Notes}

1. The following illustrates the current tensions. On June 23, 1992, following four days of heavy fighting in the right-bank city of Bendery, Vitalii Balin, a 61-year-old economist, was attacked at his place of work by three men, resulting in a two-week hospitalization, lengthy convalescence, and partial loss of hearing in his right ear. According to the victim's wife, one of the men, who was known to Balin, had lost his brother in the war and was under the (false) impression that Balin had been collecting money to help in the war effort. The men beat Balin and threatened to kill his family if he reported the incident. Local officials rejected the claim that was filed as a basis for initiating a criminal case against the attackers, and the Balins have decided not to pursue a civil case, according to the victim's wife, for fear of retribution (Human Rights Watch 1993, 235-6).

2. IRB document, Helsinki Commission, New York, March 9, 1993, telephone interview with a representative.

3. Soviet Jewry News $(1992,89)$ originally cited in Commission on Security and Cooperation in Europe (1993).

4. This may explain the statement on November 23, 1992, by the President of Moldova's Federation of Jewish Communities, who observed that "there is no anti-Semitism in Moldova either as a state policy or as a social phenomenon," and that the Moldovan government goes to great lengths to meet the Jewish communities needs..." (Radio Free Europe/Radio Liberty 1992, November 21). Also, Nahum Keren, a senior diplomat with Israel's embassy in Moscow and currently in charge of setting up Israel's mission in Chisinau, stated that Moldova is more hospitable for Jews than, for example, Russia, and that the Moldovan authorities' attitude toward Jews is far more considerate (Socor 1993, October 22).

5. Telephone interview by Alexander Benifand with Semyon Vaisman, President, Jewish Organizations and Communities of Moldova, co-President, Jewish Organizations and Communities of CIS, August 7, 1993.

6. Information supplied by the Weizmann Institute of Science, Israel, distributed through netnews@eclipse.Stanford.edu.
7. Interview with Vaisman, op. cit.

8. Novoe Russkoe Slovo. 1992. Cited originally in ITAR-TASS, October 28.

9. E. Danilyan, personal communication, 29 May 1993.

10. Soviet Jewry News 1992, August 30. Originally cited in Commission on Security and Cooperation in Europe 1993.

\section{References}

American Assaciation of Russian Jewry. 1992. Information Bulletin 9/10, New York, November.

Baltsam, Leonid. 1992. "Life in Moldova is becoming Unbearable." In Nash Golos (Our Voice), July-August.

Basapress. 1993. "Snegur Sends Message to Yeltsin on Dniester Issue." Chisinau, June 22.

1993. "Draft Constitution 'Violation' of Local People's Rights." April 14.

- 1993. "Russian National Salvation Front Tiraspol Branch." March 19.

Chala, Svitlana. 1993. "Government Adopts Romanian as Sole Official Language." In Holos Ukraini, April 2.

Chertok, Shimon. 1992. "Prognozi-Vesch Netochnaya (Forecasts are not exact)." In Novoe Russkoe Slovo, September 25.

Commission on Security and Cooperation in Europe. 1993. "Human Rights and Democratization in the Newly Independent States of the Former Soviet Union." Washington, D.C., January.

Department of State. 1993. "Report Submitted to the Committee on Foreign Relations." February.

Europa World Year Book: Moldova, Europa Publications, n.d.

Grevtsev, V. 1993. "This is called Terror." In Patriot. January.

Holos Ukrayiny. 1993. February 24.

Human Rights Watch. 1993. "World Report 1993."

Information and Research Branch. 1993. "Moldova, Update to Response to Information Request MD 12180." Ottawa, July 7.

Interfax. 1993. "Dniester-Gagauzia Declaration Termed 'Political Games'." Moscow, March 15.

ITAR-TASS. 1993. “State Journalists to Undergo 'Patriotism Exam'." March 13.

Kaplan, Alison. 1992. "Moldavian Jews Arrive." In The Jerusalem Post International Edition, August 15.

Memorial Human Rights Centre. 1992. "LargeScale and Gross Violations of Human Rights and the Situation in the Zone of Conflict in and Around the City of Bendery, June-July, 1992." September 11 .

Nezavisimaya Gazeta. 1993. "Calls Baburin's Actions in Tiraspol 'Outrageous'." Moscow, June 23.

Prikhodko, Natalya. 1993. "Coup Threat Exists. But it Will Not Necessarily Happen." In Nezavisimaya Gazeta, March 13.

Radio Free Europe. 1993. No 127, July 7. 